\title{
Ethics in municipal supply chain management in South Africa
}

\author{
David Fourie* \\ University of Pretoria, South Africa
}

*Corresponding author:

David Fourie, School of Public Management and Administration, University of Pretoria, Pretoria, South Africa.

Email: prof.djfourie@up.ac.za

\begin{abstract}
Corruption is an obstacle to democracy and the rule of law. In a democratic system it is therefore essential that public offices and institutions retain their legitimacy by being accountable as stewards for the scare public funds. However, in a developing country such as South Africa, it may be difficult to develop and maintain accountable political leadership in a climate that is widely acknowledged to have become corrupt. This paper reflects on the ethics and the cost of unethical behaviour in general, and of corruption in local government procurement in South Africa in particular.
\end{abstract}

\section{Keywords}

corrupt activities, ethical principles, ethics in public procurement, irregular expenditure, legislative framework, poor consequence management practices 


\section{Introduction}

There is currently considerable negative public sentiment in South Africa about the perceived levels of corruption in all spheres of government. Widespread despondency about the pervasiveness of corruption in the public sector and the interface between the public and the private sector has turned cynical terms such as 'tenderpreneur' and 'state capture' into colloquialisms indicating corrupt beneficiation from procurement processes and other expenditure instituted by the government.

In recent years, a number of senior government officials have been dismissed and/ or faced prosecution for corrupt activities. The reports on state capture titled 'State of capture', released in October 2016 by the Public Protector, and 'Betrayal of the promise: how South Africa is being stolen', published by the State Capacity Research Project in May 2017, reveal unethical and corrupt behaviour. Corruption Watch (2014: n.p.) states that this problem starts with the president and that any efforts by the government to tackle corruption are 'countered by the continuing impunity on the part of those who were politically and financially powerful'. It adds that the public sector corruption challenge could not be demonstrated in a more poignant manner than by the fact that 'R215 million of public money [has been] diverted away from the public good to upgrade President Jacob Zuma's private homestead' (Corruption Watch, 2014: n.p.). Given the media focus on the unethical behaviour of prominent public figures and large government institutions, it is hardly surprising that procurement activities and unethical behaviour in supply chain processes at the local government level have gone largely unnoticed. The focus of this paper is ethical considerations relating to local government supply chain activities. Local government is the closest sphere to the people and is at the right place to provide high quality and sustainable services in every way, be it collectively or in a manner that resembles the collective nature of the services.

This paper starts by contextualising the terms 'ethics' and 'corruption', and reflecting on the cost of unethical behaviour. Attention is then devoted to the South African legislative framework that guides the basic values and principles governing public administration, the manner in conducting procurement practices regarding the advancement of economic transformation and the enhancement of economic participation of black South Africans in the South African economy. Specific attention is given to local government legislation guiding local government procurement practices in South Africa. The paper concludes with aspects that should be taken into consideration in combatting corrupt activities in the public sector supply chain.

\section{Contextualisation of ethics}

Ethics is defined by the Oxford dictionary as 'moral principles that govern a person's behaviour or the conducting of an activity' (English Oxford Living Dictionaries, n.d.). In a public sector context, Andrews (quoted by Mle, 2012: 27), defines ethics as 'standards that guide the behaviour and actions of public officials in public institutions and [that] may be referred to as moral laws'. Nagiah (2012: 21) refers to ethical behaviour as behaviour that is not only good for oneself, but also good for another. Therefore, in a public sector supply chain context, ethical behaviour requires a person to act in a way that is not only in the best interests of the institution concerned, but in a way that also meets additional stewardship criteria. Section 217 of the Constitution of the Republic of South Africa requires that, when the government enters into con- 
tracts for goods and services, it must do so in a way which is fair, equitable, transparent, competitive and cost effective (South Africa, 1996).

According to the Institute of Business Ethics (IBE, 2012: n.p.),

... organisations often have a set of values or principles which reflect the way they do business or to which they aspire to observe in carrying out their business. As well as business values such as innovation, customer service and reliability, they will usually include ethical values which guide the way business is done - what is acceptable, desirable and responsible behaviour, above and beyond compliance with laws and regulations.

That which determines what is acceptable and what is not is shaped by several factors, such as societal values, the personal values of the individual concerned, organisational values and professional values (such as the Hippocratic Oath amongst doctors). Whether such core values are expressed explicitly or not, all organisations operate on the basis of a set of core values. This typically manifests in 'how business is done around here'. According to the IBE (2012: n.p.), the 'most common ethical values found in corporate literature include: integrity, fairness, honesty, trustworthiness, respect, openness. They are commonly expressed through an ethics policy and a code of ethics'.

Internationally, there is a significant focus on ethical behaviour and the need for individuals to do some introspection and fulfil the spirit of the law, and not simply follow the letter of the law. It is simply not possible to establish rules and procedures to cover every eventuality and situation, so it is important for every individual to apply his/her mind to what is ethical. One of the virtues linked to placing the public's interests above one's own, an intrinsic aspect of ethics, is civility, which refers to an individual's actions as a citizen. Public officials who practise civility appropriate to their city or country help it to fulfil its potential by placing the common good ahead of their personal interests. Civility demonstrates the difference between ethics and law: 'While acting civilly is the right thing to do, and government bodies should encourage it, civility cannot be legislated' (Markkula Center for Applied Ethics, 2018).

A similar argument is made by the Organisation for Economic Co-operation and Development (OECD, 2016):

Integrity of actors in the procurement process may significantly reduce corruption risks. Integrity refers to upholding ethical standards and moral values of honesty, professionalism and righteousness, and it is a cornerstone for ensuring fairness, non-discrimination and compliance in the public procurement process. Therefore, safeguarding integrity is at the basis of any effort to curb corruption in public procurement. (11)

The Institute of Directors in Southern Africa (IoDSA) established the King Committee on Corporate Governance in The Committee produced the first King Report on Corporate Governance inThe King report recommended standards of conduct for boards and directors of listed companies and some state-owned enterprises. This report was widely received as the most comprehensive publication embracing corporate governance both domestically and internationally. Subsequent to this report, a number of updates have been published in 2002, 
2009 and 2016). The latest King IV Report was released on 1 November 2016. Although the Code of Corporate Governance set out in King Reports is not obligatory for local government, it does lay down important ethical standards and practices.

Chapter 3 of Section 4 of King II deals specifically with ethical practices and organisational integrity. It states that

... a company's ethics refer to the principles, norms and standards that it promotes for the guidance and conduct of its activities, internal relations and interactions with external stakeholders, in accordance with established values. Thus, ethical business conduct means that a company's stakeholders - most notably its staff - adhere to defined standards of behaviour in all their business decisions and actions. (IoDSA, 2002: 101)

Chapter 7 of the code identifies core ethical principles that all entities should practise to demonstrate commitment to organisational integrity. These are

- fairness;

- transparency;

- honesty;

- non-discrimination;

- accountability and responsibility; and

- respect for human dignity, human rights and social justice (IoDSA, 2002: 103).

The absence of ethical conduct will certainly lead to rampart corruption, administrative and managerial chaos, ignoring the rule of law, cronyism, nepotism, and many transgressions that will have a detrimental effect on service delivery in the local sphere of government.

\section{Reflecting on corruption}

Corruption can be defined as 'abusing entrusted power for personal gain' (Transparency International, 2016: n.p.). Depending on the scale and loss associated with the corruption concerned, it can be classified as grand, petty or political corruption. Grand corruption constitutes 'acts committed at a high level of government that distort policies or the central functioning of the state, enabling leaders to benefit at the expense of the public good' (Transparency International, 2016: n.p.). At a lower scale, but equally corrosive to the social fabric is 'petty corruption', which refers to 'everyday abuse of entrusted power by low- and midlevel public officials in their interactions with ordinary citizens, who often are trying to access basic goods or services in places like hospitals, schools, police departments and other agencies' (Transparency International, 2016: n.p.).

Although it might seem as if corruption in public institutions does not affect the pockets of citizens directly, it does in fact create and increase poverty and exclusion. Money intended for projects and service delivery is diverted and 'while corrupt individuals with political power enjoy a lavish life, millions of Africans are deprived of their basic needs like food, health, education, housing, access to clean water and sanitation' (Ugaz, 2015: n.p.).

It would appear that corruption in Africa is on the rise. In Transparency International's People 
and Corruption: Africa Survey 2015, approximately 43,000 people across 28 countries in subSaharan Africa were canvassed for their opinions. The majority of Africans surveyed (58\%) said that corruption had increased over the last year. This is particularly the case in South Africa, where more than four in five citizens surveyed (83\%) said they had seen corruption rise recently (Pring, 2015: 25). The situation in South Africa appears to have worsened over the last few years. In 2010, South Africa was ranked 54th out of 178 countries on Transparency International's corruption index, which ranks perceived levels of public sector corruption, using a scale of 0-100, where 0 is highly corrupt and 100 is very clean. The rating is given across a number of factors of 4.5 out of 10. In the sub-Saharan Africa region, South Africa was ranked fifth most corrupt of the 47 sub-Saharan countries. By 2016, South Africa had dropped to 64th spot amongst 176 countries (Transparency International, 2016: n.p.).

Crime Watch is a South African watchdog organisation which was launched in January 2012. During its first year of operation, it received more than 3223 reports of corruption from across South Africa; the highest concentration of reports came from Gauteng. From the reports received by this body, and of particular interest to this paper, was the fact that about a quarter of all incidents revolved around corruption in local government, although the organisation did not immediately say which local governments were the worst culprits. An article published in The Independent as far back as 2013 stated that corruption 'has been widely reported in procurement, with people channelling funds to personal accounts, exerting power to cover up for corrupt acts, and distributing funds and food to secure votes in local elections'.

\section{What facilitates corruption?}

The OECD (2009: 24) has warned that corruption tends to arise when certain conditions occur in a country:

Corruption opportunities usually arise where the existing control systems are weak or malfunction; where a sanction regime is not strong enough; where the officials concerned have sufficient authority or discretion to make decisions which circumvent the rules, have the scope and ability to act in conditions of secrecy and lack integrity, allowing them to contemplate opportunities to act corruptly; and where private sector parties are able to solicit government business discreetly and dishonestly, or are willing to conspire with dishonest officials.

Situations that leave an opening for corruption include the principal/agent situation, poor transparency, weak systems, incompetent officials, conflicts of interest, urgent tenders (e.g. when preference can be given by an official by requesting a supplier to quote - a verbal request, sometimes at the last minute), seeking justification to bend the rules, multijurisdictional corruption (deals between parties in two different countries, e.g. arms deals), weak accountability arrangements and weak internal controls (Mantzaris, 2014: 68).

\section{South Africa's legislative framework}

In Chapter 10 of the Constitution, basic values and principles governing public administration are set out. Sections 95 (1) and (2) state that public administration must be governed by the democratic values and principles enshrined in the Constitution, and especially that a high standard of professional ethics must be promoted and maintained (South Africa, 1996). 
The Preferential Procurement Policy Framework Act, 5 of 2000 and the Preferential Procurement Regulations of 2017 establish the obligation of the government to award preferential procurement points to enterprises owned by historically disadvantaged persons, including women (South Africa, 2000a). The Act stipulates that when a government department assesses contracts, it must take into account a preference point system which prescribes functionality, price and Reconstruction Development Programme goals as mentioned in the Constitution. The Act is closely aligned to the Broad-Based Black Economic Empowerment (BBBEE) Codes of Good Practice.

The Broad-based Black Economic Empowerment Act, 53 of 2003 (South Africa, 2003a) as amended by Broad-Based Black Economic Empowerment Amendment Act, 46 of 2013 (South Africa, 2013) has as its fundamental objective the advancement of economic transformation and the enhancement of economic participation of black South Africans in the South African economy. The enactment of the Act has resulted in all businesses' being required to be assessed in terms of their B-BBEE compliance levels in order to remain competitive. In addition, the BBBEE Codes of Good Practice ('the Codes') guide and measure the progress of transformation in the economy. This serves as a framework with which to measure the level of compliance per entity regarding its ownership, skills development, management control preferential procurement, employment equity, socio-economic development and enterprise development.

The Prevention and Combating of Corrupt Activities Act, 12 of 2004 makes corruption and related activities an offence (South Africa, 2004). The Act establishes a register that places certain restrictions on persons and enterprises convicted of corrupt activities relating to tenders and contracts, and impose the duty on those in authority to report certain corrupt transactions. Chapter 5 of the Act provides for the establishment of a register for tender defaulters. Section 28 determines that the government is prohibited from entering into any agreement with a convicted person or enterprise. It also provides for penalties relating to corrupt offences, as well as imprisonment ranging from a period not exceeding three years to imprisonment for life.

In the government sector, the mandate of the Public Sector Commission (PSC) is to promote values and principles of public administration via the Public Sector Code of Conduct, and in line with the Constitution, throughout the Public Service. In accordance with this mandate, the PSC established a code of conduct for public officials. According to the code, all employees must perform their duties in a loyal and dedicated manner. Employees should not, either officially or in their private capacity, do anything that would or could amount to fraud or theft. They should not allow any interference or influence in the performance of their duties that could affect their objectivity or create a perception of actual or potential prejudice or favour to certain parties (Nagiah, 2012: 58).

\section{Local government legislation}

Local government is the third tier of government in South Africa. It is tasked, according to section 152 of the Constitution of the Republic of South Africa, to achieve five basic objectives, namely to:

- provide democratic and accountable government for local communities;

- promote social and economic development of their communities;

- promote a healthy and safe environment; 
- encourage the involvement of communities and community organisations in the matters of local government by consulting with the community and letting the community participate in the decisionmaking process; and

- provide basic services to communities in a sustainable manner - services such as water and sanitation, electricity, refuse removal, health and fire-fighting services, public transport and roads and parks (South Africa, 1996).

Sustainable, efficient and cost-effective provision of services by local government is threatened and can even be interrupted by corrupt and unethical practices in the supply chain process when goods and services are procured from providers. For example, the Vhembe Municipality was affected by protests due to poor service delivery in 2017. This municipality was accused of misusing procurement regulations to appoint service providers who charged inexplicably high fees (Saba, 2018). In particular, claims had been made that the municipality abused section 32 of the Local Government: Municipal Finance Management Act, 56 of 2003, which sets out the Municipal Supply Chain Management Regulations that allows for a municipality to procure goods and services under contracts secured by other organs of state (South Africa, 2003b), but only if, according to the Practice note SCM 4 of 2003 - Code of Conduct for Supply Chain Management Practitioners,

- the contract has been secured by that organ of state by means of a competitive bidding process applicable to that organ of state;

- the municipality has no reason to believe that such a contract was not validly procured;

- there are demonstrable discounts or benefits for the municipality to do so; and

- those other organs of state and the provider have consented to such procurement in writing (National Treasury, 2003).

In itself, using a service provider appointed by another organ of state that meets these requirements is legally acceptable. It would appear that the Vhembe Municipality used the supplier appointed, but at highly inflated prices that had no relevance to the original tender award. Serious ethical questions can be raised regarding how a seemingly legal process intended to ensure supply chain integrity could have been abused and perverted (Saba, 2018).

The Local Government: Municipal Systems Act, 32 of 2000 defines the legal nature of a municipality and clarifies the executive and legislative powers of municipalities (South Africa, $2000 b)$. It establishes a framework for municipal planning, performance management and the use of resources. Section 6 of the Act states that the administration of a municipality must:

- be responsive to the needs of the local community;

- facilitate a culture of public service and accountability amongst staff; and

- take measures to prevent corruption.

The Act further provides in section 80 (1) that, if a municipality decides to provide a municipal service through a service delivery agreement, it must select the service provider through selection processes which are competitive, fair, transparent, equitable and cost effective, and allow all prospective service providers to have equal and simultaneous access to information relevant to the bidding process to minimise the possibility of fraud and corruption. 
Chapter 11 of the Local Government: Municipal Finance Management Act, 56 of 2003 deals with supply chain matters. Section 112 states that, in line with the Constitution, the supply chain management (SCM) policy of a municipality or municipal entity must be fair, equitable, transparent, competitive and cost effective (South Africa, 2003b). Furthermore, it should comply with a prescribed regulatory framework for municipal SCM which must provide for measures to:

- combat fraud, corruption, favouritism and unfair and irregular practices in municipal SCM; and

- promote ethics of officials and other role players involved in municipal SCM.

Section 115 of the Act deals with the implementation of system of SCM and states that the accounting officer of a municipality or municipal entity must

a. implement the supply chain management policy of the municipality or municipal entity; and

b. take all reasonable steps to ensure that proper mechanisms and separation of duties in the supply chain management system are in place to minimise the likelihood of fraud, corruption, favouritism and unfair and irregular practices.

The National Treasury issued a practice note, SCM 4 of 2003, which contained a code of conduct for SCM practitioners. In accordance with regulation 46(4) and 46(5) of the Local Government: Municipal Finance Management Act, 56 of 2003 (South Africa, 2003b) and the Municipal Supply Chain Management Regulations (South Africa, 2005), the SCM policy of a municipality or municipal entity is required to take into account the National Treasury's code of conduct for SCM practitioners or may alternatively adopt the National Treasury code of conduct. Once the code of conduct has been adopted, it becomes binding on all officials and other role players involved in the implementation of the SCM policy of the municipality or municipal entity.

\section{Corruption in the public sector supply chain}

Mantzaris (2014: 68) describes public procurement as 'those government administrative activities that concern the purchasing of the goods and services that the government need from the private sector'. Procurement is fundamental to the government's service delivery system and promotes aims which are certainly secondary to the primary aim of procurement, for instance, using procurement to encourage social, industrial or environmental policies. Public procurement has been granted constitutional status in South Africa, and it is recognised as a means of addressing past discriminatory policies and practices (Ambe, 2016: 1). Public procurement is one of the government's activities that are most vulnerable to corruption. In addition to the volume of transactions and the financial interests at stake, corruption risks are exacerbated by the complexity of the process, close interaction between public officials and businesses, and the multitude of stakeholders (OECD, 2016: 6). In this regard, Mantzaris (2014: 68) explains the multiple risks as follows:

Corrupt practices specific to procurement transactions include bribery, extortion, embezzlement, nepotism, patronage systems, fraud, kickback schemes, false invoices, overpaying, fronting in Black Economic Empowerment (BEE) companies, inflated prices, unnecessary purchases, payments made for goods or services not received, ghost suppliers on the 'preferred suppliers list', the use of shell companies, and 'facilitation fees' required by state officials (a type of bribery). 
Purcell (2016: 102) reports that, in the Australian and New Zealand Biennial Bribery and Corruption Survey for 2013, KPMG concluded that it is difficult to quantify the total cost of corruption, because of undetected or unreported frauds. Most public sector fraud occurred in the tendering process, and that it was reported that corruption represented approximately $30 \%$ by value of all reported public sector incidents.

Mantzaris (2014: 68) identifies other forms of bid rigging. These include collusive bidding (in such cases, the bidders agree beforehand who should win the tender, there are secret agreements regarding compensation, inflated profit taking or taking turns to win tenders) and improperly awarded tenders (including possibilities for corruption during the tender evaluation and decision-making phases). Those who present the information from the evaluators to the decision-makers are often in a unique and strong position to influence decisions.

\section{The cost of unethical behaviour}

Corruption affects societies in a multitude of ways other than purely financially. This can include loss of life, freedom and health. The cost associated with corruption can be divided into four primary categories, namely political, economic, social and environmental costs. It must be understood that the most damaging effect of corruption is the corrosion of the social fabric of society, as corruption undermines trust in the political system, in institutions and in leadership. According to Transparency International (2016: n.p.), a 'distrustful or apathetic public can then become yet another hurdle to challenging corruption'.

The exact impact of unethical behaviour including corruption is impossible to quantify. For example, it has been claimed that South Africa has lost R700 billion in public money to corruption since the advent of democracy in 1994 (Chiumia and Van Wyk, 2015), but there are no accurate statistics and the true cost cannot really be determined. In addition, it is difficult to distinguish between wasteful, irregular and unauthorised expenditure and that lost due to corruption.

The Construction Sector Transparency Initiative (COST), a multi-stakeholder initiative spanning four continents, works with governments, industry and local communities to get better value from public infrastructure investment by increasing transparency and accountability. COST (2012) estimates that 'annual losses in global construction through mismanagement, inefficiency and corruption could reach USD 2.5 trillion by 2020' (n.p.). In the European Union, corruption more generally is estimated to cost $€ 120$ billion per year, which represents approximately $1 \%$ of the EU GDP and represented slightly less than the annual budget of the EU in 2014, which amounted to $€ 143$ billion (OECD, 2016).

Last but not least, one of the costs is the environmental degradation caused by nonenforcement of the relevant regulations and legislation. By paying bribes, some companies are able to access ecologically sensitive areas and avoid the cost of rehabilitating the land after the economic life of the asset (Transparency International, 2016). This could result in careless exploitation of resources and damage to entire ecological systems.

\section{Local government procurement in South Africa}

SCM seeks to ensure the proper flow of goods and services between a supplier and local 
government, whilst achieving value for money goals, empowerment principles and Local Economic Development to ensure effective service delivery. It is one of the key tools for the South African government to implement a policy for socio-economic development and transformation. The National Treasury adopted SCM in 2001, as a result of the findings of the Joint Country Assessment Review in association with the World Bank. The National Treasury issued an SCM policy document entitled Supply chain management: a guide for accounting officers and authority in municipalities and municipal entities in 2005 to guide the implementation of SCM. According to Ambe (2016: 1), the 'main objective for the adoption was to use SCM as a tool to manage 'procurement', since there was lack of interpretation, accountability and implementation of the preferential procurement policy adopted after the first democratic elections'.

In terms of the status of municipal procurement practices, every year, the Auditor General of South Africa releases a general report on local government audit outcomes. This report emphasises irregular expenditure. Such expenditure does not necessarily represent wastage, or imply that fraud has been committed, but it does refer to nonadherence to policies and SCM processes, and other irregularities. In its 2015/16 report, the Auditor General (2016) states:

Irregular expenditure had increased by just over $50 \%$ since the previous year to R16,81 billion - the highest since we started tracking the values. The amount could be even higher, as a third of the municipalities disclosed that the full amount was not known and $24 \%$ were qualified as the amount they disclosed was incomplete. (13)

In discussing the increase in irregular expenditure, the Auditor General (2016) states:

...the significant increase can be attributed overall to a weakening in SCM at municipalities, particularly in the areas of competitive bidding (46\%) and obtaining three quotations (56\%) ... the management of contracts also regressed (44\%) and there had been no improvement in addressing the concerns we have raised year after year about contracts being awarded to employees, councillors, their families and other state officials.... (13)

The Auditor General notes that, although not all non-compliance with SCM legislation results in irregular expenditure, the correlation between poor SCM practices and the high occurrence of irregular expenditure at municipalities is noteworthy.

Moreover, the Auditor General (2016) indicated an apathetic attitude to addressing the problem areas identified:

Last year, we reported 1648 instances of suppliers submitting false declarations of interest as part of the procurement processes, but $47 \%$ of the municipalities did not investigate any of the cases we reported to them - this year, we reported 2015 instances. Instances of employees not declaring interests had an even lower investigation rate, with $64 \%$ of the municipalities not investigating any of the cases. In 2015-16, we reported poor and non-compliant consequence management practices at $61 \%$ of the municipalities - an increase from the $53 \%$ in the previous year. (14) 
The Auditor General has pointed out that municipalities with poor consequence management practices were more susceptible to fraud and corruption, as municipal officials were not being held accountable for their actions or omissions.

In the report, the Auditor General indicates the level of SCM practices that has been found to be irregular as set out in Table 1.

Table 1. Auditor General's findings on SCM practices (2013-2016).

\begin{tabular}{llll} 
Findings on SCM practices & $2013 / 14(\%)$ & $2014 / 15(\%)$ & $2015 / 16(\%)$ \\
\hline $\begin{array}{l}\text { Awards to employees and councillors } \\
\quad \text { or other state officials }\end{array}$ & 26 & 19 & 20 \\
$\begin{array}{l}\text { Awards to close family members of } \\
\quad \text { employees and councillors }\end{array}$ & 34 & 30 & 28 \\
$\begin{array}{l}\text { Uncompetitive or unfair procurement processes } \\
\text { Inadequate contract management }\end{array}$ & 75 & 76 & 83 \\
\hline
\end{tabular}

Source: Auditor General (2016: 46). SCM: supply chain management.

A total of R16 523 million (which equates to 98\%) of the irregular expenditure in 2015/16 was a result of non-compliance with SCM legislation. The Auditor General (2016) concludes that the there was little movement in the level of total SCM findings (material plus non-material findings) in any of the SCM areas from the previous year 'except in the areas of uncompetitive or unfair procurement processes and inadequate contract management, which had regressed since the previous year' (46).

\section{Local government supply chain issues}

In his article on international cooperation against corruption, Robert Klitgaard (1998: 1), who is considered one of the giants of anti-corruption research, refers to a 'corruption formula': $\mathrm{C}=\mathrm{M}+$ D-A ('Corruption equals monopoly plus discretion minus accountability'). Translated into local government terms, this is relevant, because municipalities are constitutionally required to provide a number of monopolist services that cannot be provided by any other service provider, such as water distribution, refuse removal and sanitation. When considering the procurement of services and the appointment of service providers, municipalities have a large degree of discretion. If a local authority deviates from the prescribed procurement processes for nonapproved reasons and if the accountability culture is not strong, these actions can create an environment that is conducive to corruption.

According to the Auditor General, it is a matter of particular concern that more than $60 \%$ of municipalities did not comply materially with SCM legislation, as revealed in the comments cited above. It is a serious concern that the Auditor General reports that their audits identified that around $40 \%$ of the municipalities did not have all the required mechanisms in place, such as policies, codes of conduct, fraud reporting mechanisms, and record keeping of processes for reporting and investigating possible fraud. The following common findings were reported: 
- no disciplinary board had been established at 73 municipalities;

- a fraud hotline was absent at 53 municipalities; and

- there were no policies for investigations at 50 municipalities.

This contributed to the fact 'that $52 \%$ of municipalities had findings on inadequate follow-up of allegations of financial and SCM misconduct and fraud' (Auditor General, 2016: 58). The Auditor General identified potential fraudulent activities in the supply chain process at $61 \%$ of municipalities audited. The main categories of the fraudulent activities were the following:

- suppliers submitted false declarations of interest;

- payments were made to possible fictitious suppliers;

- payments were made in spite of poor delivery by suppliers;

- there were other SCM-related allegations; and

- employees failed to disclose an interest in a supplier.

The Auditor General further found that in more than half of the municipalities, the council failed to conduct the required investigations into all instances of unauthorised, irregular and fruitless and wasteful expenditure that were reported in the previous year. The most damning finding was that the highest contributors to irregular expenditure were linked to poor consequence management by the municipalities (Auditor General, 2016: 61).

It is evident that, despite all the national and local government legislation and substantial legal and anti-corruption frameworks that have been put in place, the problem of the abuse of funds and lack of accountability in the supply chain at the local government level remains a very real problem. From the Auditor General's report, it is clear that there has been little to no progress in addressing the shortcomings and problem areas identified year after year. In most cases, the situation is regressing. Without the necessary ethical leadership and the political will to take a stance against the misuse of public funds, the malpractices identified will continue unabated.

\section{Combatting corrupt activities in the supply chain}

The OECD argues that safeguarding integrity must be the basis of any effort to curb corruption in public procurement. This requires policies for public officials in general and codes of conduct, and also that specific standards for supply chain officials are implemented. These should include specific restrictions and prohibitions focused on ensuring that officials' private interests do not improperly influence the performance of their public duties and responsibilities:

The most common conflict of interest situations are related to personal, family or business interests and activities, gifts and hospitality, disclosure of confidential information, and future employment. Consequently, the additional standards can include provisions on asset declaration requirements, whistleblowing procedures, and protection measures for whistleblowers. (OECD, 2016: 11)

A number of OECD countries have introduced a specific code of conduct for SCM officials which specifically addresses matters of conflict of interest and combines this with training and programmes to ensure integrity and public accountability. The OECD also recommends the 
promotion of transparency and open government, including actively ensuring full access to information and open data, along with active and timely responses to request information, as safeguards of integrity and public interest. It also emphasises that transparency in the public service is strongly related to integrity and an anti-corruption stance, but that this relationship is not automatic and depends on several conditional factors that need to be in place for effective accountability: 'In order for citizens and civil society organizations to fulfil an oversight role, as so-called watchdog, data availability needs to be paired with timeliness, data quality, processing capacity, effective reporting and whistle-blower channels' (OECD, 2016: 15).

It would also appear that the involvement of various relevant external stakeholders during the stages of procurement can increase transparency and integrity, whilst assuring an adequate level of scrutiny, provided that confidentiality, equal treatment and other legal obligations in the procurement process are maintained.

Finally, the use of information and communication technologies in public procurement (eprocurement) can contribute to increased transparency and facilitate access to public tenders. Eprocurement could potentially reduce direct interaction between procurement officials and companies and increase competition by allowing for easier detection of irregularities and corruption, such as bid-rigging schemes: 'The digitalisation of procurement processes strengthens internal anti-corruption controls and detection of integrity breaches, and it provides audit services trails that may facilitate investigation activities' (OECD, 2016: 22).

\section{Conclusion}

This paper has reflected on unethical behaviour, especially corruption and fraud, as a worldwide phenomenon that has far- reaching negative consequences on citizens, as it has an impact on their lives in a multitude of ways. The public sector in South Africa is not immune to this scourge. Much has been written about and reported regarding the failings of public officials, from the president to municipal employees.

Procurement and supply chain activities play a major part in the government's vision of bringing about social and economic change in South Africa, so several pieces of legislation have been passed in the last two and a half decades governing financial management, accountability in local government and supply chain practices. Unfortunately, as the reports by the Auditor General and other entities such as the PSC show, this legislation has not brought about the desired effects, and fraud and corruption and other unethical practices continue.

The question then is what can be done about this situation. Continued review of legislation, regulations and processes is required as an ongoing activity, but this alone is insufficient. It is crucial to create a climate where people are held accountable for their actions and ethical standards are created and upheld from the highest officebearers to the lowest. This requires the leadership to take a stance against unethical behaviour and to set an example that others will be able to follow. Also, as the Auditor General has repeatedly indicated, there needs to be robust evaluation and investigation of instances of noncompliance with SCM requirements, and there must be tangible consequences where any unethical practice or situation is identified. In addition, South Africa needs to implement the best practices identified by the OECD to assist the establishment of a culture that is ethical, and to ensure that supply chain activities achieve the 
objectives set out in the Constitution.

\section{Declaration of Conflicting Interests}

The author(s) declared no potential conflicts of interest with respect to the research, authorship, and/or publication of this article.

\section{Funding}

The author(s) received no financial support for the research, authorship, and/or publication of this article.

\section{References}

Ambe IM (2016) Public procurement trends and developments in South Africa. Research Journal of Business and Management 3(3): 1.

Auditor General (2016) Consolidated Report on the Local Government Audit Outcomes 2015/16. Pretoria. Available at: www.agsa. co.za/Portals/0/MFMA 2014-15 (accessed 13 January 2018).

Chiumia S and Van Wyk A (2015) Has South Africa lost R700 billion to corruption since '94? Available at: www.africacheck.org/reports/has-sa-lost-r700-billion-to-corrup tion-since1994-why-the-calculation-is- wrong/ (accessed 5 January 2018).

Corruption Watch (2014) Why is corruption getting worse in South Africa? Available at: www.corruptionwatch.org.za/why-is-corrup tion-getting-worse-in-south-africa/ (accessed 13 January 2018).

COST (Construction Sector Transparency Initiative) (2012) Our story. Available at: www.constructiontransparency.org/home (accessed 12 January 2018).

English Oxford Living Dictionaries (n.d.) Ethics. Available at: www.en.oxforddictionaries.com/definition/ethics (accessed 12 January 2018).

IBE (Institute for Business Ethics) (2012) Ethical values and codes. Available at: www.ibe.org. uk/ethical-values-and-codes/102/52 (accessed 2 January 2018).

Independent (2013) Local government most corrupt, says watchdog. Available at: www.iol.co.za/news/crime-courts/local-government- most-corrupt-says-watchdog-1462699 (accessed 12 January 2018).

Institute of Directors in Southern Africa (2002) King Report on Corporate Governance for South Africa. Sandown, Sandton: The Institute of Directors in Southern Africa.

Klitgaard R (1998) International cooperation against corruption. Finance \& Development 35(1): 1.

Mantzaris E (2014) Public procurement, tendering and corruption. Realities, challenges and tangible solutions. African Journal of Public Affairs 7(2): 68.

Markkula Center for Applied Ethics (2018) Santa Clara University. Available at: www. scu.edu/ethics/focus-areas/government- ethics/resources/what-is-government-ethics/ civility/ (accessed 2 January 2018). 
Mle TR (2012) Professional and ethical conduct in the public sector. Africa's Public Service Delivery and Performance Review 1(1): 27.

Nagiah K (2012) The code of conduct of the South African Public Service compared with International Guidelines. Unpublished Master's Dissertation, University of Pretoria, South Africa.

OECD (Organisation for Economic Co-operation and Development) (2009) Publications on Regulatory Impact Analysis: Regulatory Impact Analysis: A Tool for Policy Coherence. Paris: OECD.

OECD (Organisation for Economic Co-operation and Development) (2016) Preventing Corruption in Public Procurement. Paris: OECD.

Pring C (2015) People and Corruption: Africa Survey 2015. Global Corruption Barometer. Berlin, Germany: Transparency International. Available at: www.transparen cy.org (accessed 12 January 2018).

Purcell AJ (2016) Australian local government corruption and misconduct. Journal of Financial Crime 23(1): 102-118.

National Treasury (2003) Practice Note SCM 4 of 2003. Code of Conduct for Supply Chain Management Practitioners. Pretoria: National Treasury.

Saba A (2018) Vhembe racks up R1-billion in unauthorised, irregular spending. Mail \& Guardian. Available at: www.mg.co.za/arti cle/2018-01-18-clouds-over-vuwani-custodian (accessed 22 January 2018).

South Africa (1996) Constitution of the Republic of South Africa Act, 108 of 1996. Pretoria: Government Printer.

South Africa (2000a) Preferential Procurement Policy Framework Act, 5 of 2000. Pretoria: Government Printer.

South Africa (2000b) Local Government: Municipal Systems Act, 32 of 2000. Pretoria: Government Printer.

South Africa (2003a) Broad-Based Black Economic Empowerment Act, 53 of 2003. Pretoria: Government Printer.

South Africa (2003b) Local Government: Municipal Finance Management Act, 56 of 2003. Pretoria: Government Printer.

South Africa (2004) Prevention and Combating of Corrupt Activities Act, 12 of 2004. Pretoria: Government Printer.

South Africa (2005) Municipal Supply Chain Management Regulations. Notice 868 of 2005. Pretoria: National Treasury.

South Africa (2013) Broad-Based Black Economic Empowerment Amendment Act, 46 of 2013. Pretoria: Government Printer. 
Transparency International (2016) Corruption perceptions index 2016. Available at:

www.transparency.org/news/feature/corruption_perceptions_index_2016 (accessed 13 January 2018).

Ugaz J (2015) Corruption in Africa: 75 million people pay bribes. Transparency International. Available at:

www.transparency.org/news/featurecorruption_in_africa_75_million_people_pay_bribes (accessed 16 January 2018). 